\title{
BRIEF OF BUILDING INFORMATION MODELLING FOR INDONESIAN ARCHITECTURE
}

\author{
Rona Fika Jamila ${ }^{1}$ )*, Gentina Pratama Putra ${ }^{1}$ ), Bangun IR Harsritanto ${ }^{2}$ ) \\ *) Corresponding author email : ronafika@gmail.com
}

1.) Architecture Department, Universitas Mercu Buana, , Jakarta - Indonesia

2.) Architecture Department, Universitas Diponegoro, Semarang - Indonesia

\author{
Article info \\ MODUL vol 19 no 1, issues period 2019 \\ Doi : :10.14710/mdl.19.1.2019.15-18 \\ Received : 22nd november 2018 \\ Revised : 20th april 2019 \\ Accepted : 1sy may 2019
}

\begin{abstract}
Building information modelling (BIM) is a system that integrates multi-dimensional aspects of construction project at every phase. Simply said BIM unified all project databases from and to all stakeholders. This system still continuously developed and widely spread on each countries construction projects. In architecture, the BIM has been revolute the human resource requirements on the projects. Indonesia as developing country is still performing transitions from large worker project into more compact projects; from centralized projects into decentralized project. The BIM system has been a mandatory in several Indonesia big infrastructure projects to plan, simulate, design and deliver databases for making more quick decision making and improve the facilities. This paper aim is describing the benefit-challenge factors of BIM adoption on Indonesia architecture projects and the potential driving factors of BIM application. This study was qualitative paradigm with analysis method of selected literatures and previous research paper review which stratified by the cases. The results of this study are BIM bring the high efficiency and represent the complete skills for an architect. However the high initial cost of technology and human investment, the unsupported regulation and conventional system resistant challenged the Indonesia architecture society to adopt BIM. Furthermore the Indonesia architecture education is still struggling to learn and teach the BIM as an integral part in studio as the agent of change.
\end{abstract}

Keywords: BIM; adoption;Indonesia;review; benefits challenges factors

Rona Fika Jamila, Gentina Pratama Putra, Bangun IR Harsritanto

\section{INTRODUCTION}

Technology has been grown in exponential curve in recent years. The trend of automatization and digitalization was unavoidable and literary unstoppable. Starting from the chip invention on 1960's, human innovation and research think tank have collaborated with machine and artificial logic to spread wider and dig deeper the technology to assist human1. In other hand, Infrastructure projects of Indonesia have been growing fast and vast. The current government also set development of Indonesia infrastructure as top priority. In addition, the investment in infrastructure construction project was estimated around $5.2 \%$ per year increasement. Due to those Indonesia conditions, the risk of delayed infrastructure project is high. The delayed project may influence especially to the cost of project and generally to all area of a construction site. In example of traffic jam in big city also affected the congested area which leads to huge economic loss is the development of LRT project and upper toll. During the construction, the traveling time from Jakarta to Cikampek resulted 2 hours delayment. Therefore, logistic deliver cost rose because of multiple traveling times. So an adopted technology to work the project on schedule is mandatory 2. The BIM system has been a mandatory in several Indonesia big infrastructure projects to plan, simulate, design and deliver databases for making more quick decision making and improve the facilities. The BIM was adopted by many countries such: United State of America, United Kingdom countries, Australia, South Korea, China, even Malaysia and Nigeria also.

Indonesia reacted slowly to the trend of construction innovation as usual. In the past, transformation of manual drawing into Computer Aided Design was happened in early 90's even though the first development of 2 Dimension of digital drawing by AutoCAD was released in 80's. Through the era 2000's the 3 dimensional drawings were supported by many plugins and render machine to make it more real. Those situations shown the gap between Indonesia and world 
innovation has reach a decade in the beginning. Nevertheless the internet has brought a fast bridge to this gap especially in the private sectors compared to the government and public sector of Indonesia architecture areas.

The promising integration system of BIM has been initiated by Indonesia diaspora and internet in early 2010's and still penetrated in the many architectural projects. Due to the deeper penetration of promising system of BIM, this paper aimed to describes the benefit-challenge factors of BIM adoption on Indonesia architecture projects and the potential driving factors of BIM application. This paper advocates and advert the BIM to architects and architecture enthusiast so them will join in learning and applying the system on their project.

\section{METHODS}

This study was performed in qualitative paradigm of research to explore and persuade. The study analysis methods are selected literatures and previous research paper review. The literatures were chosen and stratified by the cases. Firstly the motivation factors then secondly the benefits and the challenge at last part.

\section{DISCUSSION}

\section{The motivation factors}

The BIM as mentioned has been adopted in several countries regardless their status. The developed countries which already adopted the system for their architectural projects are USA, UK, Australia, and South Korea. In the developing countries the Malaysia and Nigeria has integrated the BIM in to their project standard (see figure 1)

\begin{tabular}{|l|l|}
\hline country & \multicolumn{1}{|c|}{ BIM motivation factors } \\
\hline USA & $\begin{array}{l}\text { Strategy to decrease resistance } \\
\text { Stakeholder accepts the BIM } \\
\text { Adequate Training } \\
\text { Support in management }\end{array}$ \\
\hline UK & $\begin{array}{l}\text { Adopting collaborative method and approach } \\
\text { Providing staff experience with the BIM } \\
\text { Developing standard using BIM }\end{array}$ \\
\hline Australia & $\begin{array}{l}\text { Providing good support in management } \\
\text { Developing strategies on cooperative work, } \\
\text { conflict resolution and reduce resistant } \\
\text { Developing plan for BIM in government level } \\
\text { improving IT infrastructures and soft-hardwares } \\
\text { BIM regulations }\end{array}$ \\
\hline South Korea & $\begin{array}{l}\text { Encouraging the using of new technology } \\
\text { Providing training } \\
\text { Developing institution commitment on BIM } \\
\text { Government set mandatory BIM usage in projects }\end{array}$ \\
\hline China & $\begin{array}{l}\text { Preparing BIM validation tools } \\
\text { Pressure by government } \\
\text { Coordination among stakeholders }\end{array}$ \\
\hline Malaysia & $\begin{array}{l}\text { Government support } \\
\text { Adequate training } \\
\text { Support on senior management }\end{array}$ \\
& $\begin{array}{l}\text { Increase the level of BIM knowledge } \\
\text { Expanding research toward BIM }\end{array}$ \\
\hline & \\
& \\
&
\end{tabular}

\begin{tabular}{|l|l|}
\hline & $\begin{array}{l}\text { Adequate training and support } \\
\text { Facilitate educational institution for the BIM } \\
\text { advocacy } \\
\text { Government obligation of BIM in projects }\end{array}$ \\
\hline
\end{tabular}

Figure 1. Summary of BIM motivation factors

(Hatem et al, 20183)

The developed country like USA the stakeholder's acceptance brings BIM adoption level is easier especially after each stakeholder knew that it able to assist their coordination regardless their ages. The government also try to reduce the resistance in their people about BIM convert by providing adequate training to improve cooperation skills. In the UK, the integration of BIM and the construction society has reach the design team level and already developed the use of BIM standard in their regulations and guidelines. This collaboration between humans and the regulations has multiple effects toward the construction project based on BIM. The China has done alternate approach toward BIM integrations. The validation of BIM tools and communist government pressure motivate the architect construction society to obey the system. In those situations the coordination amongst stakeholders will be better under pressure.

Australia has more effort to motivate their construction society. The efforts are providing support training to managements, operational staff and investors, developing strategies on cooperative work, conflict resolution and reduce resistant, improving IT infrastructures and BIM regulations. The strategies force the improvement in software and hardware. Furthermore other chained party such: educators, suppliers, programmers also motivated to support the BIM. South Korea as the fastest internet speed and wired country has confidence toward new technology and commitment to develop their country. The monoculture people were catalyst for the application of BIM regulation with no resistance.

In developing countries like Malaysia and Nigeria, the support of government to train and regulate motivated the people to use BIM system to their architecture construction projects. In addition the educator also play important role in initiating the BIM migration.

The various countries motivations factors were concluded as three factors: trainings of BIM, regulation deployment and preparation of tools (software, hardware and IT infrastructure). In Indonesia situations, those motivation factors shall be compromised quickly to reach the integration with BIM.

\section{The benefits}

The applications of BIM compared to the conventional style were studied in several cases by Indonesian researchers. The results showed that: 1 . Integration of softwares in compact package, 2 . design 
collision early detection, 3. faster process, 4. Resources efficiency, and 5. Cost reduction 4. In case of 20 storey buildings the design process can be reduced $50 \%$ by using BIM and the human resources recruitment only demanded the minimum requirement of the conventional one. (See figure 2)

\begin{tabular}{|c|c|c|c|c|c|c|}
\hline \multirow[t]{2}{*}{ Enterprise } & \multicolumn{2}{|c|}{$\begin{array}{l}\text { Time } \\
\text { allocation } \\
\text { (month) }\end{array}$} & \multicolumn{2}{|c|}{$\begin{array}{l}\text { Human resource } \\
\text { Allocation } \\
\text { (personal) }\end{array}$} & \multirow[t]{2}{*}{$\begin{array}{l}\text { BIM } \\
\text { advantages }\end{array}$} & \multirow[t]{2}{*}{$\begin{array}{l}\text { BIM } \\
\text { disadvantage } \\
\mathrm{s}\end{array}$} \\
\hline & BIM & conv & BIM & conv & & \\
\hline $\begin{array}{l}\text { Total } \\
\text { Bangun } \\
\text { Persada } \\
\text { (revit) }\end{array}$ & $3-6$ & $3-12$ & $5-6$ & $\begin{array}{l}\text { Minimum } \\
6\end{array}$ & $\begin{array}{l}\text { Minimize } \\
\text { revision } \\
\text { Easy } \\
\text { coordination } \\
\text { Efficiency } \\
\text { in cost } \\
\text { mokeup }\end{array}$ & $\begin{array}{l}\text { High initial } \\
\text { cost } \\
\text { Need } \\
\text { multidiscipli } \\
\text { nary based } \\
\text { personal }\end{array}$ \\
\hline $\begin{array}{l}\text { Wiratman } \\
\text { \& Assoc } \\
\text { (revit) }\end{array}$ & $5-6$ & $8-12$ & $5-6$ & $\begin{array}{l}\text { Minimum } \\
6\end{array}$ & $\begin{array}{l}\text { Early error } \\
\text { inspection } \\
\text { on }\end{array}$ & $\begin{array}{l}\text { Incompatible } \\
\text { with detail } \\
\text { less than } \\
1: 20 \quad \text { High } \\
\text { specification } \\
\text { Hardware }\end{array}$ \\
\hline $\begin{array}{l}\text { Pratiwi } \\
\text { Putri } \\
\text { Sulung } \\
\text { (Tekla) }\end{array}$ & 6 & 6 & 4 & $\begin{array}{l}\text { Minimum } \\
10\end{array}$ & $\begin{array}{l}\text { Tweak the } \\
\text { work }\end{array}$ & None \\
\hline
\end{tabular}

Figure 2. Comparison of BIM and conventional in case of 20 storey building design

(Cinthya ABP et al, 2016)

\section{The challenges}

Assuming the previous Cinthya et all research the weaknesses of BIM were: high cost of licenced software, requirement of high specifications hardware/computers, disabilities in small scale of detail drawing4. In other study by Chandra (2017) the various brand compatibility problems, transition of behaviour and BIM still unavailable for all project were the top three challenges in appliance5. (see figure 3)

\begin{tabular}{|l|l|l|}
\hline No & description & Mean \\
\hline 1 & Cost of modelling & 3.75 \\
\hline 2 & Training & 3.73 \\
\hline 3 & Transition & 4.15 \\
\hline 4 & Different brand & 4.27 \\
\hline 5 & Less of Innovation & 3.73 \\
\hline 6 & Existing Technology & 3.27 \\
\hline 7 & Resistance to learn & 3.35 \\
\hline 8 & Unavailable for all projects & 3.92 \\
\hline 9 & Lack of legal & 3.23 \\
\hline 10 & Behaviour risk & 3.81 \\
\hline 11 & Responsibility & 3.77 \\
\hline
\end{tabular}

Figure 3. Challenges in BIM application

(Chandra et all, 2017)

The transition habit was explained as resistance and training problem which can be solved by the time expenses. The habit may be forced by the regulation by the supervisor or government to speed up the transition in need. The various brand compatibility problems and unavailability for all project problems can be described as the dis-integrations between software and their tasks. In example of Autodesk flagship brand on their task: building system software is Revit Architecture, HVAC is Revit MEP and energy analysis using Ecotect (see figure 4).

In 2012, the project tasks of one single building must be analysed by three different softwares. The three sofwares resulted longer processing time if client demanded the total design of building design with optimization of HVAC using by energy analysis. The three requirements itself couldn't be done in one process design. Therefore in figure 5 the explanation of process simulation can be seen to imagine the time requirement to have one house design with HVAC and energy calculation6. This situation in later years and development may be solved by Autodesk software developers by add ons or plugins integration in one major software like Revit. However the software may demand higher computer specifications. The higher specs resulted higher initial costs either.

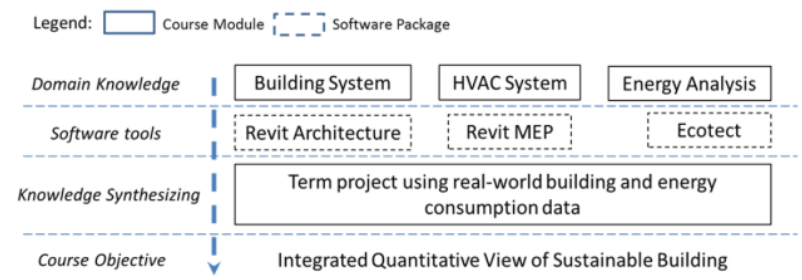

Figure 4. Composition of Projects Objective (Shen Z, 2012)

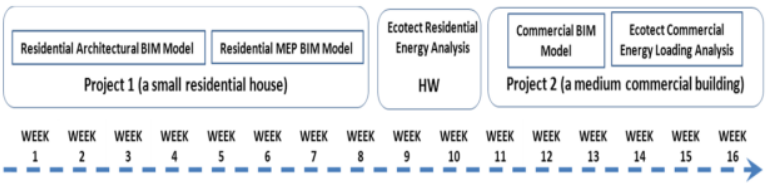

Figure 5. Timeline for one assignment

(Shen Z, 2012)

Whether the motivation factors, benefits and challenges, Indonesia shall change their paradigm in design for betterment and further infrastructure developments7. The paradigm alteration needs support not only from the government, private sectors and architecture practitioners but also from the educator in courses or universities. The sustainable preparation from the architects making until the strict regulation may bring the improvement in Indonesia architecture projects.

\section{CONCLUSIONS}

Indonesia is facing infrastructure development era. The demands of more accurate, integrated and efficient system are high. The BIM bring the high efficiency and represent the complete skills for an architect. However the high initial cost of technology and human investment, the unsupported regulation and conventional system resistant challenged the Indonesia architecture society to adopt BIM. The motivation factor 
of those aspects shall be concerned to speed up the integration of BIM in Indonesia architecture projects.

\section{REFERENCES}

Gunama MG and Latifa NF Automatictecture : Otomatisasi Penuh dalam Arsitektur Masa Depan Arsitektur NALARs Volume 16 Nomor 1 p 4360

GBG Indonesia Indonesia's Construction \& Building Materials Sector On the Up \& Up Global Business Guide Indonesia (2016) accessed at :

http://www.gbgindonesia.com/en/property/article/2016/i ndonesia_s_construction_andamp_building_mate rials_sector_on_the_up_andamp_up_11586.php

Hatem WA et al 2018 Motivation Factor For Adopting Building Information Modelling (BIM) in Iraq Engineering Technology Applied Science Research vol 8 no 2 p 2668-2672

Cinthya ABP et al 2016 Perbandingan Waktu Biaya dan Sumber Daya Manusia Antara Metode Building Information Modelling (BIM) dan Konvensional (studi kasus Perancangan Gedung 20 Lantai) Jurnal Karya Teknik Sipil vol 5 no 2 p 220-229

Chandra HP et al (2017) Building Information Modelling in Architecture Engineering Construction Project in Surabaya Proceedia Engineering 171 348-353

Shen Z et al 2012 Teaching Sustainable Design Using BIM and Project Based Energy Simulation Edus Sci 2 136-149

Bangun IR Harsritanto 2018 Urban Environment Development based on Universal Design Principles, E3S Web of Conferences 31, 09010

\section{ACKNOWLEDGMENTS}

Thank to Universitas Mercubuana for the fundings and supports. The credits to our colleagues for assisting and discussion the manuscript writtings. 